\title{
IMPACT OF PATIENT COUNSELLING ON KNOWLEDGE, ATTITUDE, PRACTICES OF PATIENTS WITH TYPE 2 DIABETES MELLITUS AT A TERTIARY CARE TEACHING HOSPITAL
}

\author{
AJIN K GEORGE ${ }^{1 *}$, JEWEL VG ${ }^{1}$, MEENU MANOHAR $^{1}$, SARATH P KUMAR ${ }^{1}$, MUNEERUDEEN J $^{2}$
}

${ }^{1}$ Pharm. D. Intern, Department of Pharmacy Practice, Bapuji Pharmacy College, Davanagere, Karnataka, India. ${ }^{2}$ Assistant Professor, Department of Pharmacy Practice, Bapuji Pharmacy College, Davangere, Karnataka, India. Email: nellivila.3@gmail.com

Received: 10 February 2017, Revised and Accepted: 25 February 2017

\section{ABSTRACT}

Objective: To evaluate the impact of counseling in terms of knowledge, attitude, practices (KAP) outcomes. To counsel the diabetic patients about their disease, medications, and lifestyle modifications that are necessary for proper disease management.

Materials and Methods: A randomized prospective controlled study was conducted for 6 months in the general medicine outpatient department of SSIMS and RC. Patients enrolled were randomized into test and control groups. Suitably designed and validated KAP questionnaire was applied at baseline and final follow-up for both groups.

Results: At the end of the study, knowledge and attitude levels were markedly improved in test group patients. The fasting blood sugar of the patients in the test group were found to be significant $(\mathrm{p}<0.00)$ when compared from baseline to second assessment whereas in control group, no significant changes were observed $(* p>0.05)$.

Conclusion: The study concluded that the improved knowledge and attitude clearly indicates the benefits of pharmacist-provided counseling although they did not translate into improved practice outcomes. The study observed that hospital pharmacists can play a key role in the management of diabetes mellitus and patient care.

Keywords: Knowledge; attitude; practices, Patient counseling, Type 2 diabetes mellitus.

(C) 2017 The Authors. Published by Innovare Academic Sciences Pvt Ltd. This is an open access article under the CC BY license (http://creativecommons. org/licenses/by/4. 0/) DOI: http://dx.doi.org/10.22159/ajpcr.2017.v10i5.17637

\section{INTRODUCTION}

The worldwide prevalence of diabetes mellitus (DM) has risen dramatically over the past two decades. It is a silent disease that has become more prevalent with increased age [1]. Keeping in view the alarming increase in the incidence and prevalence of DM in India, the World Health Organization has declared India as the "Diabetic Capital of the World" [2].

The prevalence of DM is dramatically rising worldwide; 171 million people suffered from diabetes in 2000 , and it is expected that this figure will double to 366 million by 2030 [3].

DM refers to a group of common metabolic disorders that share the phenotype of hyperglycemia. Depending on the etiology of DM, factors contributing to hyperglycemia include reduced insulin secretion, decreased glucose utilization, and increased glucose production [4]

Lack of insulin affects the metabolism of carbohydrate, proteins, and fat resulting in significant disturbances in water and electrolyte homeostasis. Death may result from acute decompensation [5]. Complications of DM are frequently divided into macrovascular and microvascular. The general etiology of both complications is the same and results from atherosclerosis of the vessels which may lead to occlusion [6].

The American Diabetes Association recommends using the fasting glucose as the principal tool for the diagnosis of DM in non-pregnant adults [7].

Patient counseling refers to the process of providing information, advice, and assistance to help patients use their medications appropriately. The information and advice is given by the pharmacist directly to the patient or to the patient's representative and may also include information about the patient's illness or recommended lifestyle changes [8].

A knowledge, attitude, practices (KAP) survey is a quantitative method (predefined questions formatted in standardized questionnaires) that provides access to quantitative and qualitative information.

There is increasing recognition within the international aid community that improving the health of poor people across the world depends on adequate understanding of the sociocultural and economic aspects of the context in which public health programs are implemented. Such information has typically been gathered through various types of crosssectional surveys, the most popular and widely used being the KAP survey, also called the knowledge, attitude, behavior and practice survey [9-12].

In KAP surveys, the knowledge part is normally used only to assess the extent of community knowledge about public health concepts related to national and international public health programs. KAP study reveals that what people know about certain things, how they feel and also how they behave. The knowledge acquired by a community refers to their comprehension of any given topics [13]. Previous studies have shown that knowledge on disease and medications were essential in effective diabetes self-care [14].

Measuring attitudes is the second part of a standard KAP survey questionnaire. The term attitude is usually used to refer to a person's general feelings about an issue, object, or person. Furthermore, attitudes are interlinked with the person's knowledge, beliefs, emotions, and values, and they are either positive or negative [13].

A third and integral part of KAP surveys is the investigation of healthrelated practices. Questions normally concern the use of different treatment and prevention options and are hypothetical [13]. 
Table 1: Number of patients (test group and control group) who had correctly answered the KAP questionnaire

\begin{tabular}{|c|c|c|c|c|}
\hline \multirow[t]{2}{*}{ Knowledge questions } & \multicolumn{2}{|l|}{ Test group } & \multicolumn{2}{|l|}{ Control group } \\
\hline & Baseline $(n=75)$ & End point $(n=68)$ & Baseline $(n=75)$ & End point $(n=59)$ \\
\hline Diabetes is a condition in which the body contains: & 50 & 58 & 48 & 50 \\
\hline The symptom(s) of diabetes is/are: & 30 & 36 & 34 & 36 \\
\hline Diabetes, if not treated & 18 & 26 & 16 & 18 \\
\hline The most accurate method of monitoring diabetes is: & 39 & 44 & 52 & 57 \\
\hline $\begin{array}{l}\text { The lifestyle modification(s) required for diabetic patients } \\
\text { is/are: }\end{array}$ & 40 & 49 & 45 & 47 \\
\hline $\begin{array}{l}\text { The important factors that help in controlling blood sugar } \\
\text { are: }\end{array}$ & 50 & 56 & 50 & 52 \\
\hline The well-balanced diet includes: & 36 & 45 & 24 & 22 \\
\hline Total score & 271 & 338 & 282 & 297 \\
\hline
\end{tabular}

KAP: Knowledge, attitude, practices

Table 2: Responses to attitude questions

\begin{tabular}{|c|c|c|c|c|}
\hline \multirow[t]{2}{*}{ Attitude questions } & \multicolumn{2}{|l|}{ Test group } & \multicolumn{2}{|l|}{ Control group } \\
\hline & Baseline $(n=75)$ & End point $(n=68)$ & Baseline $(n=75)$ & End point $(n=59)$ \\
\hline \multicolumn{5}{|c|}{ Do you exercise regularly? } \\
\hline No & 48 & 31 & 43 & 32 \\
\hline \multicolumn{5}{|l|}{ How often? } \\
\hline Every day & 17 & 25 & 29 & 23 \\
\hline Once weekly & 9 & 12 & 3 & 4 \\
\hline Once monthly & 1 & 0 & 0 & 0 \\
\hline \multicolumn{5}{|c|}{ Are you following a controlled and planned diet? } \\
\hline Yes & 54 & 61 & 53 & 39 \\
\hline No & 21 & 7 & 22 & 20 \\
\hline \multicolumn{5}{|l|}{ How often? } \\
\hline Always & 35 & 42 & 33 & 35 \\
\hline Sometimes & 19 & 19 & 20 & 4 \\
\hline Rarely & 0 & 0 & 0 & 0 \\
\hline \multicolumn{5}{|c|}{ Do you miss taking the doses of your diabetic medication? } \\
\hline No & 52 & 62 & 52 & 39 \\
\hline \multicolumn{5}{|l|}{ How often? } \\
\hline Occasionally & 23 & 6 & 23 & 20 \\
\hline Once a week & 0 & 0 & 0 & 0 \\
\hline Once a month & 0 & 0 & 0 & 0 \\
\hline
\end{tabular}

Self-care education is an essential element in the treatment of a person with DM, and its importance is acknowledged in several studies carried out in communities with different socioeconomic and cultural profiles. Patient education also plays a critical role in facilitating patients' acceptance of their diagnosis and understanding behavioral changes required for active participation in treatment [15].

\section{MATERIALS AND METHODS}

Materials used

Informed consent form:

- Patient data collection form

- Patient information leaflet

- KAP questionnaire adapted from P and T Journal Medimedia USA.

\section{Ethical issues}

The ethical clearance for the study was obtained from Institutional Ethical Committee of Bapuji Pharmacy College, Davangere.

\section{Methods}

The study was conducted in the general medicine outpatient department of a tertiary care teaching hospital for 6 months. Patients diagnosed with Type 2 DM of either sex above 30 years were included in the study. Patients with gestational diabetes, thyroid disease, and with uncontrolled diabetes were excluded from the study. After the enrollment, patients were randomized into test and control groups. The data collected from the case sheet (patients' demographic details, levels of random blood sugar, fasting blood sugar [FBS], and post-prandial blood sugar) were properly documented in a previously designed data collection form. Suitably designed and validated KAP questionnaire was administered at baseline and at the final follow-up on all the study patients to assess the disease awareness and its management. The patients in the test group received counseling on their disease, drugs, diet, and lifestyle modification and also patient information leaflet highlighting the disease, diet, and lifestyle modifications. The patients in the controlled group received pharmacist-provided counseling and patient information leaflets only at the end of the study.

\section{RESULTS}

After the scrutiny, using inclusion and exclusion criteria, 150 patients were enrolled in the study and were randomized into test and control groups. Out of them, 127 patients (68 from test and 59 from control group) completed all follow-ups of the study. Among 150 patients, $48.66 \%$ were males and $51.33 \%$ were females. When categorizing age wise, the majority of patients (28\%) were found in the age group of 51-60. Most of the patients had primary level education and were unemployed. Among the study population, $88.66 \%$ of the patients were non-smokers and $56.66 \%$ were non-alcoholics. Among the patients, only $45(30 \%)$ had a family history of DM and $62(41.33 \%)$ had other complications. Nearly $44.66 \%$ patients enrolled were with above 5 years of diabetes disease history. 
Table 3: Responses to practice questions

\begin{tabular}{|c|c|c|}
\hline \multirow[t]{2}{*}{ Practice questions } & \multicolumn{2}{|l|}{ Frequency (\%) } \\
\hline & Test group $(n=75)$ & Control group $(n=75)$ \\
\hline \multicolumn{3}{|c|}{ When did you have your last eye examination? } \\
\hline 6 months back & $20(26.7)$ & $20(26.7)$ \\
\hline 1 year back & $17(22.7)$ & $11(14.7)$ \\
\hline 2 years back & $12(16.0)$ & $8(10.7)$ \\
\hline Not done at all & $13(17.3)$ & $15(20.0)$ \\
\hline \multicolumn{3}{|c|}{ When was your last urine examination? } \\
\hline 1 month back & $20(26.7)$ & $17(22.7)$ \\
\hline 6 months back & $20(26.7)$ & $19(25.3)$ \\
\hline 1 year back & $18(24.0)$ & $22(29.3)$ \\
\hline Not done at all & $17(22.7)$ & $17(22.7)$ \\
\hline \multicolumn{3}{|c|}{ When was your blood sugars last checked? } \\
\hline 2 weeks back & $18(24.0)$ & $20(26.7)$ \\
\hline 1 month back & $45(0.0)$ & $47(62.7)$ \\
\hline 6 months back & $10(13.3)$ & $6(8.0)$ \\
\hline \multicolumn{3}{|c|}{ When were your lipids last checked? } \\
\hline 1 month back & $10(13.3)$ & $12(16.0)$ \\
\hline 6 months back & $12(16.0)$ & $16(21.3)$ \\
\hline 1 year back & $19(25.3)$ & $21(28.0)$ \\
\hline Not at all & $34(45.3)$ & $26(34.7)$ \\
\hline
\end{tabular}

Table 4: Comparison of FBS values within the group

\begin{tabular}{|c|c|c|c|c|c|c|}
\hline \multirow[t]{2}{*}{ Comparison of FBS values } & \multirow{2}{*}{$\begin{array}{l}\text { Baseline } \\
1\end{array}$} & \multirow{2}{*}{$\begin{array}{l}1^{\text {st }} \text { assessment } \\
2\end{array}$} & \multirow{2}{*}{$\frac{2^{\text {nd }} \text { assessment }}{3}$} & \multicolumn{3}{|c|}{ Paired t-test } \\
\hline & & & & 1 versus 2 & 1 versus 3 & 2 versus 3 \\
\hline \multicolumn{7}{|l|}{ Test group } \\
\hline Mean \pm SD & $173.23 \pm 56.92$ & $154.80 \pm 45.20$ & $136.45 \pm 40.25$ & $\mathrm{p}<0.000$ & $\mathrm{p}<0.000$ & $\mathrm{p}<0.000$ \\
\hline \multicolumn{7}{|l|}{ Control group } \\
\hline Mean \pm SD & $174.97 \pm 38.34$ & $173.95 \pm 38.00$ & $173.41 \pm 38.16$ & $\mathrm{p}=0.09$ & $\mathrm{p}<0.01$ & $\mathrm{p}=0.159$ \\
\hline
\end{tabular}

FBS: Fasting blood sugar, SD: Standard deviation

The knowledge distribution of both control and test group patients regarding DM is shown in Table 1. The patients were assessed for different aspects of DM, what is DM, its types, symptoms using KAP questionnaire containing eight knowledge questions. In test group, patient's knowledge score was increased from baseline whereas no observable changes were found in control group.

Table 2 shows the attitude responses of patients toward DM. There was a positive trend in the attitude toward DM in the test group.

Table 3 shows the percentage distribution of answers to the practice questions.

The mean scores of FBS in test and control during their each followup were compared using student's t-test. The $p$ value was found to be highly statistically significant in the test group as shown in Table 4.

\section{DISCUSSION}

The management of DM not only requires the prescription of appropriate nutritional and pharmacological regimen by the physician but also intensive education and counseling of the patient. A total of 150 patients were enrolled in the study. Out of that one expired, five patients were hospitalized, and 17 did not respond. Remaining 127 patients (68 patients from test and 59 from control group) completed all the follow-ups.

A significant improvement in knowledge and attitude perception has been observed in the test group of the study population, who received patient counseling and patient information leaflet, whereas the levels remained more or less same in the control group. However, the number of patients who changed their practices which needs to be followed remains same in both control and test group in the final assessment. The total knowledge score of the test group patients was found to be 338. However, the studies conducted by Adepu et al., Mohammad et al., and Hrushikesh et al. showed that KAP of the patients improved whereas no improvement was observed in a study carried out in Nepal by Upadhyay et al. However, some study findings illustrated that although the patient's knowledge got increased, levels of attitude remain unchanged [1,16-18].

The FBS of the patients in the test group were found to be significant $\left({ }^{*} \mathrm{p}<0.00\right)$ when compared from baseline to second assessment whereas in control group, no significant changes were observed $(* p>0.05)$. This result was supported by the reports of a study conducted by Adepu et al. $(* \mathrm{p}>0.05)[1]$.

\section{CONCLUSION}

The study concluded that the improved knowledge and attitude clearly indicates the benefits of pharmacist-provided counseling although they did not translate into improved practice outcomes. Therefore, there is a need for structured programs to improve the practices of patients.

There was a reduction in FBS level and improvement in the quality of life in test group patients. The study observed that hospital pharmacists can play a key role in the management of DM and patient care. We conclusively state that pharmacist-provided patient counseling may be a useful tool for decision-making in planning and monitoring disease interventions to improve health outcome.

\section{REFERENCES}

1. Adepu R, Rasheed A, Nagavi BG. Effects of patient counselling on quality of life in Type-2 diabetes mellitus patients in two selected 
South Indian community pharmacies: A study. Int J Pharm Sci 2007;69(4):519-24.

2. Michell G, Mary J, Rajesh I. Knowledge of diabetes, its treatment and complications amongst diabetic patients in a tertiary care hospital. Indian J Community Med 2008;33(3):204-6.

3. Balaiah S, Tirupa M, Narayana G, Mohanraj R, Balaiah SP, Tirupa M, et al. Assessment of pharmaceutical care services on health related QOL in patients with Type 2 diabetes mellitus - A prospective interventional study. Int J Pharm Pharm Sci 2014;6(7):456-61

4. Dan LG, Kaspir DL, Jameson JL, Fauci AS, Stephen LH, Loscalzo J. Diabetes mellitus. Harrisons Principles of Internal Medicine. $18^{\text {th }}$ ed. San Francisco: McGraw Hill Medical; 2012. p. 344, 2968-3003.

5. Nicki RC, Brian RW, Stuart HR. Diabetes mellitus. Davidson s Principles \& Practices of Medicine. 21 $1^{\text {st }}$ ed. New York: Churchill Livingstone, Elsevier; 2010. p. 21, 795-834.

6. Walker R, Whittlesea C. Diabetes mellitus. Clinical Pharmacy \& Therapeutics. $5^{\text {th }}$ ed. Toronto: Churchill Livingstone, Elsevier; 2012. p. $44,685-710$

7. Mohammed A, Syed SK, Qadri MR, Mohammad NI, Taj ZA, Arshad HM, et al. A cross-sectional study of analysis of knowledge of diabetes in diabetic patients and patient counselling in princess Esra Hospital. IOSR J Pharm 2014;4(4):80-93.

8. Parthasarathi G, Karin N, Nahata MC. A Textbook of Clinical Pharmacy Practice Essential Concepts and Skills. $2^{\text {nd }}$ ed. Hyderabad: Universities Press; 2012

9. Green CE. Can qualitative research produce reliable quantitative findings? Field methods. Anthropol Matters J 2001;13(3):3-19.
10. Nehring P, Beata MR, Monica K, Agnieszka SK, Rafal P, Grazina B, et al. J Diabetes Metab Disorders 2014;79:1-5.

11. Manderson L, Aaby P. An epidemic in the field? Rapid assessment procedures and health research. Soc Sci Med J 1992;35(7):839-50.

12. Nichter M. Social science lessons from research and their application to ARI. J Soc Appl Anthropol 1993;52(1):53-67.

13. Annika L. How much can a KAP survey tell us about people's knowledge, attitudes and practices? Some observations from medical anthropology research on malaria in pregnancy in Malawi. Anthropol Matters J 2009;11(1):1-12.

14. Marhanis SO, Kong LS. Diabetes knowledge and medication adherence among geriatric patient with Type 2 diabetes mellitus. Int J Pharm Pharm Sci 2014;6(3):103-6.

15. Flavia FL, Maria LS, Manoel AS, Tatiane AM, Valmi DS, Carla RS. Knowledge and attitude: Important components in diabetes education. J Enterp Resour Plan Stud 2009;17(4):468-73.

16. Mohammad A, Prabhu M, Sreenivasan N, Radha R, Sasikala C, Syed AG. Assessment of the influence of patient counselling on knowledge, attitude and practice in Type-2 diabetes mellitus patients in Kolar district of South India. Int J Pharm Res Biosci 2014;3(6):269-82.

17. Hrushikesh YR, Ashok DK, Mallesh M, Purushothaman M. Significance of patient counselling in diabetes mellitus; A prospective study. World J Pharm Pharm Sci 2015;4(8):1215-26.

18. Upadhyay DK, Subish P, Shankar PR, Mishra P. Knowledge, attitude and practice about diabetes among diabetes patients in Western Nepal. Rawal Med J 2008;33:8-11. 